Article

\title{
Recent Trend in Hydroclimatic Conditions in the Senegal River Basin
}

\author{
Ansoumana Bodian 1,* Lamine Diop ${ }^{2}$ (D), Geremy Panthou ${ }^{3}$ (D) , Honoré Dacosta ${ }^{4}$, \\ Abdoulaye Deme ${ }^{5}$ D, Alain Dezetter ${ }^{6} \mathbb{D}^{\text {, }}$, Pape Malick Ndiaye ${ }^{1}$, Ibrahima Diouf ${ }^{7}$ and
} Théo Vischel ${ }^{3}$ (D)

1 Laboratoire Leïdi “Dynamique des territoires et développement”, Université Gaston Berger (UGB), BP 234-Saint-Louis, Senegal; ndiaye.papa-malick@ugb.edu.sn

2 UFR S2ATA Unité de Formation et de Recherche des "Sciences Agronomiques de l'Aquaculture et des Technologies Alimentaires", Université Gaston Berger (UGB), BP 234-Saint-Louis, Senegal; lamine.diop@ugb.edu.sn

3 IGE Institut des Géosciences de l’Environnement, Université Grenoble Alpes, 38000 Grenoble, France; geremy.panthou@univ-grenoble-alpes.fr (G.P.); theo.vischel@univ-grenoble-alpes.fr (T.V.)

4 Département de Géographie, Université Cheikh Anta Diop, BP 5005 Dakar, Senegal; dacosta.honore@gmail.com

5 Laboratoire LSAO “Laboratoire des Sciences de l'Atmosphère et de l'Océan”, Université Gaston Berger (UGB), BP 234-Saint-Louis, Senegal; abdoulaye.deme@ugb.edu.sn

6 HydroSciences Montpellier, Univ Montpellier, IRD, CNRS, CC 057, 163 rue Auguste Broussonnet, 34090 Montpellier, France; Alain.Dezetter@ird.fr

7 NOAA Center for Weather and Climate Prediction, 5830 University Research Court, College Park, MD 20740, USA; ibrahima.diouf@noaa.gov

* Correspondence: bodianansoumana@gmail.com or ansoumana.bodian@ugb.edu.sn; Tel.: +221-77-811-7553

Received: 21 December 2019; Accepted: 20 January 2020; Published: 6 February 2020

\begin{abstract}
Analyzing trends of annual rainfall and assessing the impacts of these trends on the hydrological regime are crucial in the context of climate change and increasing water use. This research investigates the recent trend of hydroclimatic variables in the Senegal River basin based on 36 rain gauge stations and three hydrometric stations not influenced by hydraulic structures. The Man Kendall and Pettitt's tests were applied for the annual rainfall time series from 1940 to 2013 to detect the shift and the general trend of the annual rainfall. In addition, trends of average annual flow rate (AAFR), maximum daily flow (MADF), and low flow rate (LFR) were evaluated before and after annual rainfall shift. The results show that the first shift is situated on average at 1969 whereas the second one is at 1994. While the first shift is very consistent between stations (between 1966 and 1972), there is a significant dispersion of the second change-point between 1984 and 2002. After the second shift (1994), an increase of annual rainfall is noticed compared to the previous period (1969-1994) which indicates a not significant, partial rainfall recovery at the basin level. The relative changes of hydrologic variables differ based on the variables and the sub-basin. Relative changes before and after first change-point are significantly negative for all variables. The highest relative changes are observed for the AAFR. Considering the periods before and second shifts, the relative changes are mainly significantly positive except for the LFR.
\end{abstract}

Keywords: trends; Senegal River Basin; rainfall shift; hydroclimatic variables; streamflow; climate change 


\section{Introduction}

Rainfall is a major factor that conditions food production, is mainly derived from rain-fed agriculture, and plays a central role in the availability of surface and groundwater water resources [1].

Therefore, several studies have focused on how climate variability affects rainfall regime in West Africa over the last century [2,3]. A common feature of these studies is the identification of a succession of drought episodes [4]. Since the beginning of observations in 1854, three main dry periods have been recognized [2]: 1911-1913, 1940-1943 and 1968 to recent decades. Due to its duration and intensity, the latter has been recognized as the greatest drought of the last century [5]. The significant decline in annual rainfall generally led to the depletion of water resources [6,7], the amplification of water deficits [8] and the modification of natural ecosystems and socio-economic systems [4]. It had particularly negative effects on human activities and environment. The drought and its hydrological impacts have been well investigated until the 1990s [3,9-19]. However, the number of studies on hydroclimatic evolution in West Africa over the last three decades has decreased significantly because of the decline of in-situ observation networks and the difficulty for academic structures to access data from national meteorological and/or hydrological services.

Recently, some authors $[18,20,21]$ have questioned whether a few years of excess rainfall of the 1990s could be the sign of a gradual recovery of rainfall leading to more favorable hydroclimatic conditions. Similarly, Diello [22] showed that the area affected by drought has shrunk since 1994 in the Sahelian area. However, other studies have suggested that severe drought conditions were persisting in the Sahel at the end of the 1990s [12,23]. Thus, the question of the persistence or end of drought was discussed in the scientific community in early 2000.Vischel et al. [24] investigated the scientific literature on recent rainfall trends in West Africa. They pointed out that after the severe drought in the Sahel in the late 1960s, the last decade of the 20th century saw a partial recovery of rainfall, particularly in the central part of the Sahel, but without returning to the wet conditions of the 1950s and 1960s. In addition, recent studies have shown that the relative increase in rainfall accumulation was mainly linked to an increase in the intensity of rainfall events, while the occurrence of rainfall events remains at an average level close to that of periods of extreme drought $[25,26]$. Therefore, the terms "recovery" or "return to wet conditions" often used to characterize rainfall over the past two decades has to be considered with caution.

In this respect, Descroix et al. [27] argued that the end dates of the drought of the 1970s may also vary region to another. Lebel and Ali [16] then Panthou et al. [25] have shown that there are contrasts between the Western Sahel which seems to start a later recovery in annual precipitation than the central Sahel. Nkrumah et al. [26] showed that contrast also exists between sub-regions with in the Southern West Africa with a more marked increase in coastal than inland regions. It is also what Diop et al. [28] have shown in a recent study in Senegal where rainfall recovery in recent decades is significant in the coastal strip of Senegal. All these recent studies push for further analyze recent rainfall trends in West Africa at the sub-regional scale. While climatic zones or country-based approaches dominate the literature, there is a lack of analyses at the scale of regional basins in the West African region. The basin scale is a key scale, not only for analyzing climatic regional contrasts, but also to understand their impacts on water resources. In the context of climate and global changes and increasing water demand, it is a major challenge to jointly analyze rainfall and hydrological changes to improve water resource management [29].

\section{Materials and Methods}

\subsection{Study Area}

The Senegal River basin extends from the Sahara in the North to the humid tropical region of Guinea in the South [30]. It drains an area of 300,000 $\mathrm{km}^{2}$ [31] with four riparian states, from upstream to downstream, Guinea, Mali, Senegal and Mauritania (Figure 1). The Senegal River basin has experienced climate change effects since the 1970s [31]. To remedy the effects of adverse climatic 
conditions, the Senegal River Basin Development Organization (in French, Organisation pour la Mise en Valeur du Fleuve Sénégal, OMVS) built three dams (Figure 1) in 1986 (Diama), 1988 (Manantali) and 2013 (Felou). The main functions of the Diama dam are to improve irrigation in the Senegal River valley and delta and to facilitate water supply. Manantali is a multi-usage dam with a storage capacity of 11 billion $\mathrm{m}^{3}$ of water, an energy production of $800 \mathrm{GWh} /$ year and an irrigation capacity of 255,000 ha. Felou is a run-of-river dam with a production capacity of $350 \mathrm{GWh} /$ year. These various hydraulic structures have artificialized the Senegal River regime in some places. From the climate stand point, rainfall in the basin is related to the displacement of the Intertropical Convergence Zone (ITCZ) from the south to north, inducing the penetration of the West African monsoon governed by the thermal contrast between the sea and the continent [32]. Based on the latitudinal distribution of precipitation, four climatic zones have been defined in the Senegal River basin by Dione [30]: Guinea (mean annual precipitation, P > $1500 \mathrm{~mm})$; Southern Sudan $(1000<\mathrm{P}<1500 \mathrm{~mm})$; Northern Sudan $(500<\mathrm{P}<1000$ $\mathrm{mm})$; and the Sahel $(\mathrm{P}<500 \mathrm{~mm})$.

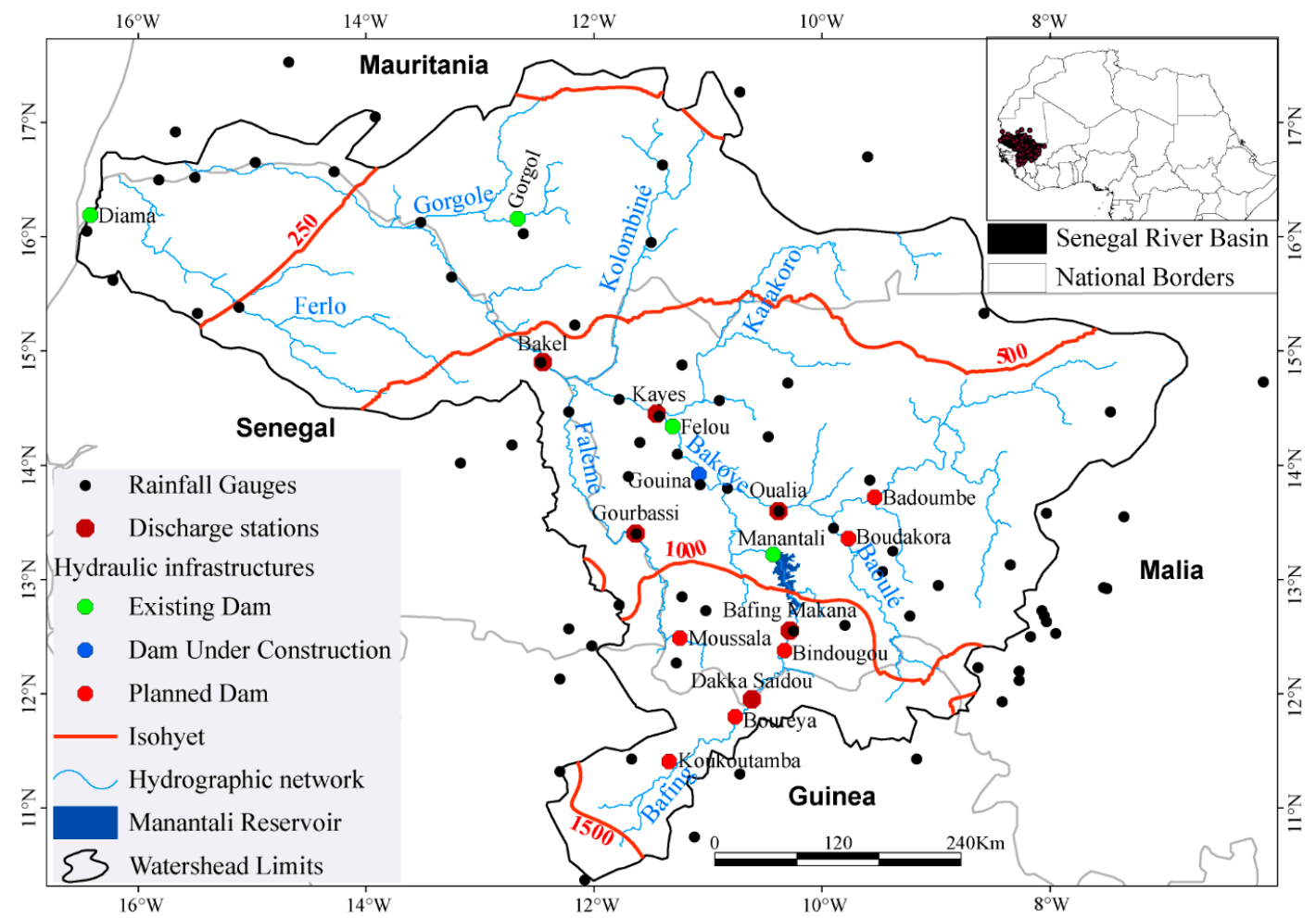

Figure 1. Senegal River Basin, hydrographic network, river flow stations, rainfall gauges, and main hydraulic infrastructures.

\subsection{Data}

In this study, in-situ annual rainfall and daily observed stream-flows data are used.

\subsubsection{Annual Rainfall data, Selected Gauges and Periods of Study}

The rainfall data used in this study come from the OMVS database that contains 80 rainfall stations (Figure 1) covering the period 1940 to 2013. For each station, the percentage of gaps in the data series has been calculated. Only stations with less than $50 \%$ of missing years were first selected, leading to retain 48 stations. Then, two criteria were used to select the final stations for the study: (i) the coefficient of determination (Figure 2a) between the observed annual rainfall and the calculated one by the Regional Vector Method [33-35] and (ii) stations with no missing values (Figure 2b). Thus, for this study, stations (36) with zero gaps or a coefficient of determination of 0.5 , which is an acceptable value in linear regression [36], were selected (Figure 2c). Figure 3 shows the available annual rainfall data 
over the period 1940-2013. For the stations with gaps, the regional vector method was used to fill the gaps. The regional vector method has already been evaluated by Bodian [37] and has shown to be robust enough to fill missing values in annual rainfall series.

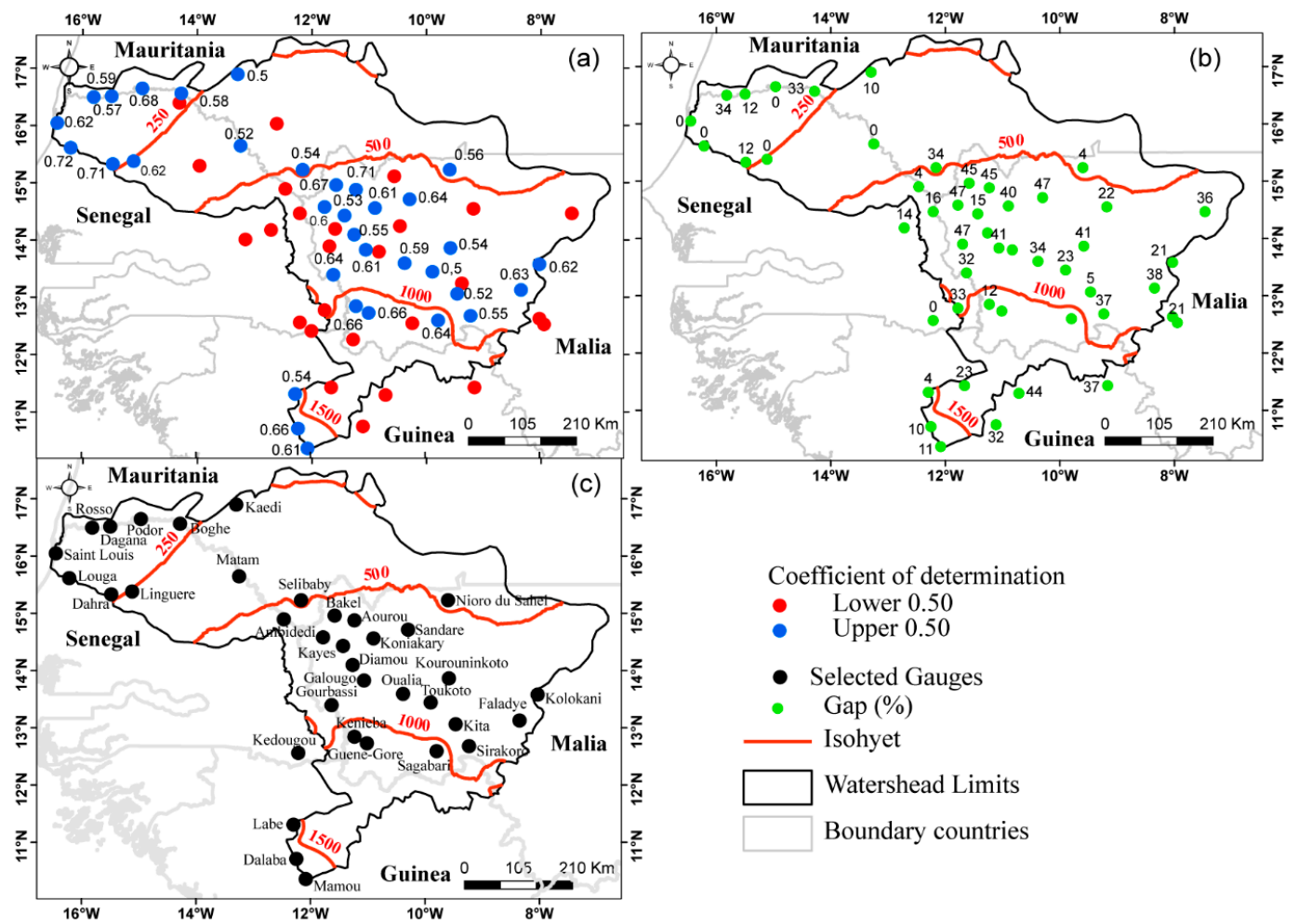

Figure 2. (a) Coefficient of determination between the observed annual rainfall and calculated by the regional vector method, (b) percentage of gap in the data series by station, (c) stations selected for the study.
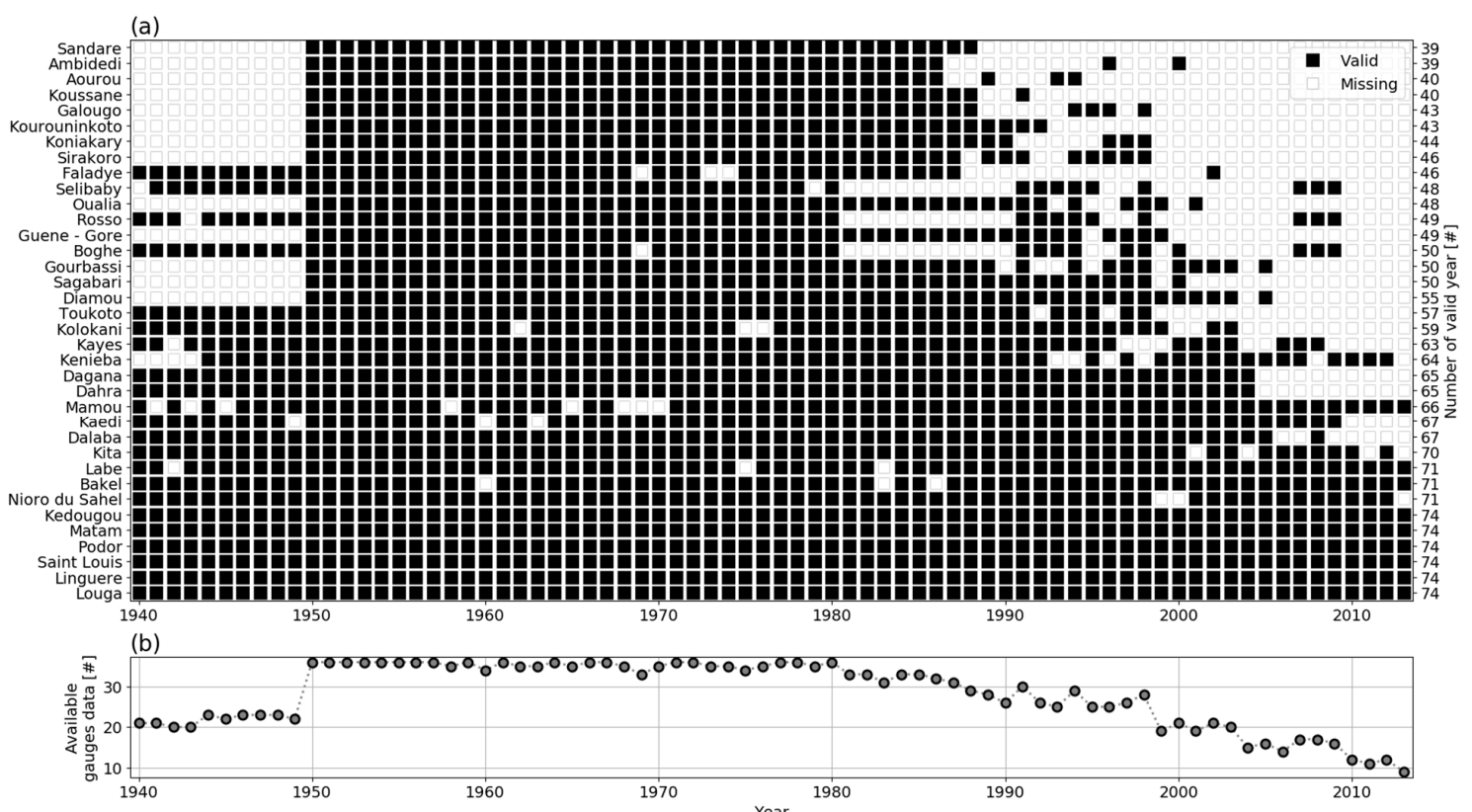

Figure 3. Available annual rainfall data over the period 1940-20131. (a) missing values by station; (b) number of available gauges data per year. 


\subsubsection{Hydrological Data}

For this study, three streamflow stations not influenced by hydraulic structures were chosen (Figure 1). Table 1 provides the available hydrometric data from the OMVS database.

Table 1. Available discharge data.

\begin{tabular}{cccccc}
\hline River Basin & Stations & $\begin{array}{c}\text { Surface } \\
\left.\mathbf{( k m}^{2}\right)\end{array}$ & $\begin{array}{c}\text { Start of Record } \\
(\mathbf{d d} / \mathbf{m m} / \mathbf{y y y y})\end{array}$ & $\begin{array}{c}\text { End of Record } \\
(\mathbf{d d} / \mathbf{m m} / \mathbf{y y y})\end{array}$ & \% Gaps \\
\hline Bafing & Dakka Saidou & 15660 & $27 / 05 / 1952$ & $21 / 04 / 2016$ & 1.02 \\
Faleme & Gourbassi & 16264 & $02 / 01 / 1954$ & $24 / 03 / 2016$ & 0.17 \\
Bakoye & Oualia & 104479 & $01 / 06 / 1954$ & $24 / 03 / 2016$ & 1.90 \\
\hline
\end{tabular}

\subsection{Methods}

\subsubsection{Hydroclimatical Variables Trend Analysis}

Two methods, namely the Mann-Kendall and Pettitt's tests, were used to detect the annual rainfall trends and shift over the entire Senegal River basin. The Mann-Kendall test [38,39] is a non-parametric test often used to detect the presence of a monotonic trend in a chronological series. The Pettitt's test [40] was used to detect the change-point in the considered series. It is based on the Mann-Whitney two-sample test and allows the detection of a single shift at an unknown time. By combining the Mann Kendall and Pettitt tests, a several-steps approach was applied. First, the Man Kendall and Pettitt's tests were applied for the annual rainfall series from 1940 to 2013 to detect the shift and the general trend of the annual rainfall. Once a change-point was detected, a new annual rainfall series was considered starting after the change point. For this new series, we applied the same tests as previously. Furthermore, trends of average annual flow rate (AAFR), maximum daily flow (MADF), and low flow rate (LFR) were evaluated before and after annual rainfall shifts.

\subsubsection{Standardized Precipitation Index (SPI)}

The SPI $[9,41]$ is a widely used index to characterize meteorological drought. It reflects a rainfall surplus or deficit for the year compared to a whole period under investigation. A positive value of SPI indicates rainfall surplus whereas a negative value shows rainfall deficit.

\section{Results}

\subsection{Temporal Variability of Annual Rainfall}

Figure 4 presents the temporal variability of the annual rainfall in the Senegal River basin. The results show that the stations exhibited different shifts. However, two regime shifts statistically significant at the $5 \%$ level are exhibited. The first change-point is situated on average at 1969 whereas the second one is at 1994 (Figure 4). While the first shift is very consistent between stations (comprised between 1966 and 1972), there is a significant dispersion of the second rupture between 1984 and 2002. The two identified shifts lead to distinguish three different periods as depicted by the SPI (Figure 5). From 1940 to 1968, the mean SPI is positive and reveals annual rainfall well above the interannual mean characterizing a very wet period. By contrast, the inter-shift period displays very negative values of SPI showing that the Senegal River basin clearly witnessed the well-documented Sahelian great drought. The dispersion of the break date shows that the identification of an end date for the drought period is much less consistent with some stations remaining very dry while others seem to be starting to recover more quickly. 


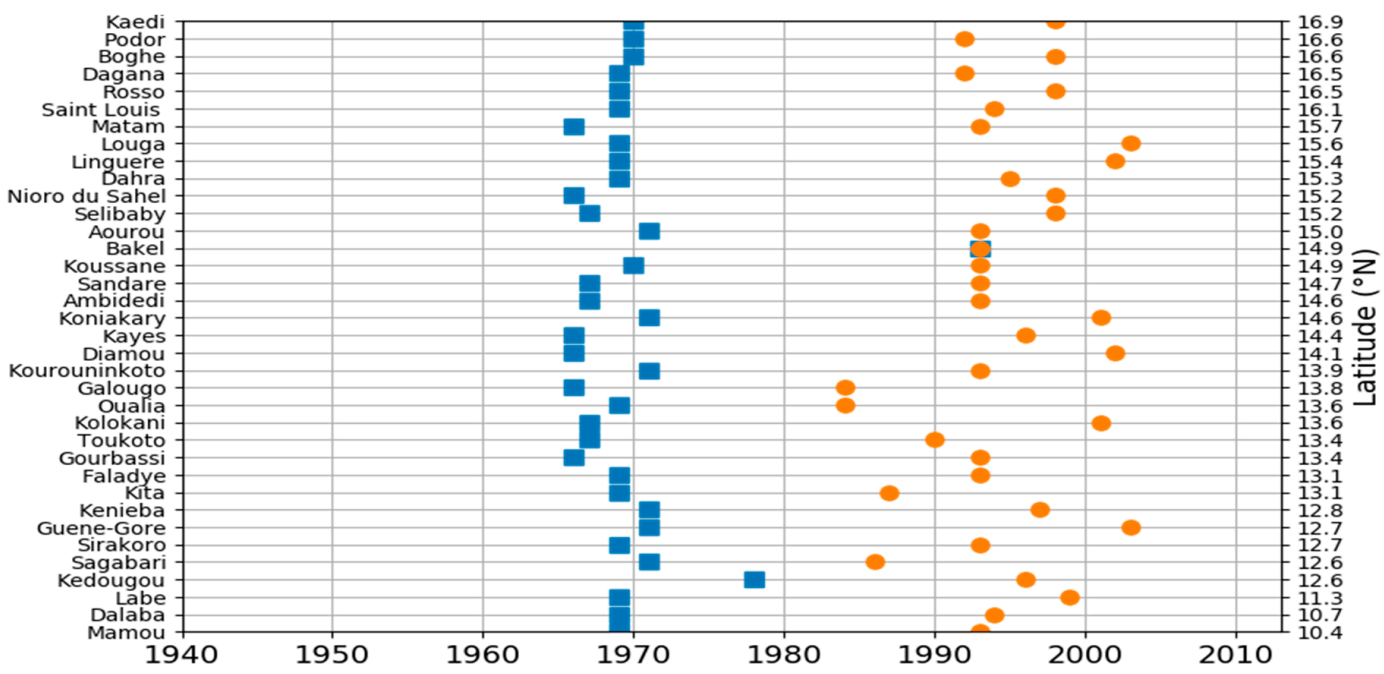

Figure 4. Breaks identified in the annual rainfall series by the Pettitt test at $5 \%$ level. The blue dots represent the year of occurrence of the first shift and the orange dots the year of occurrence of the second shift.

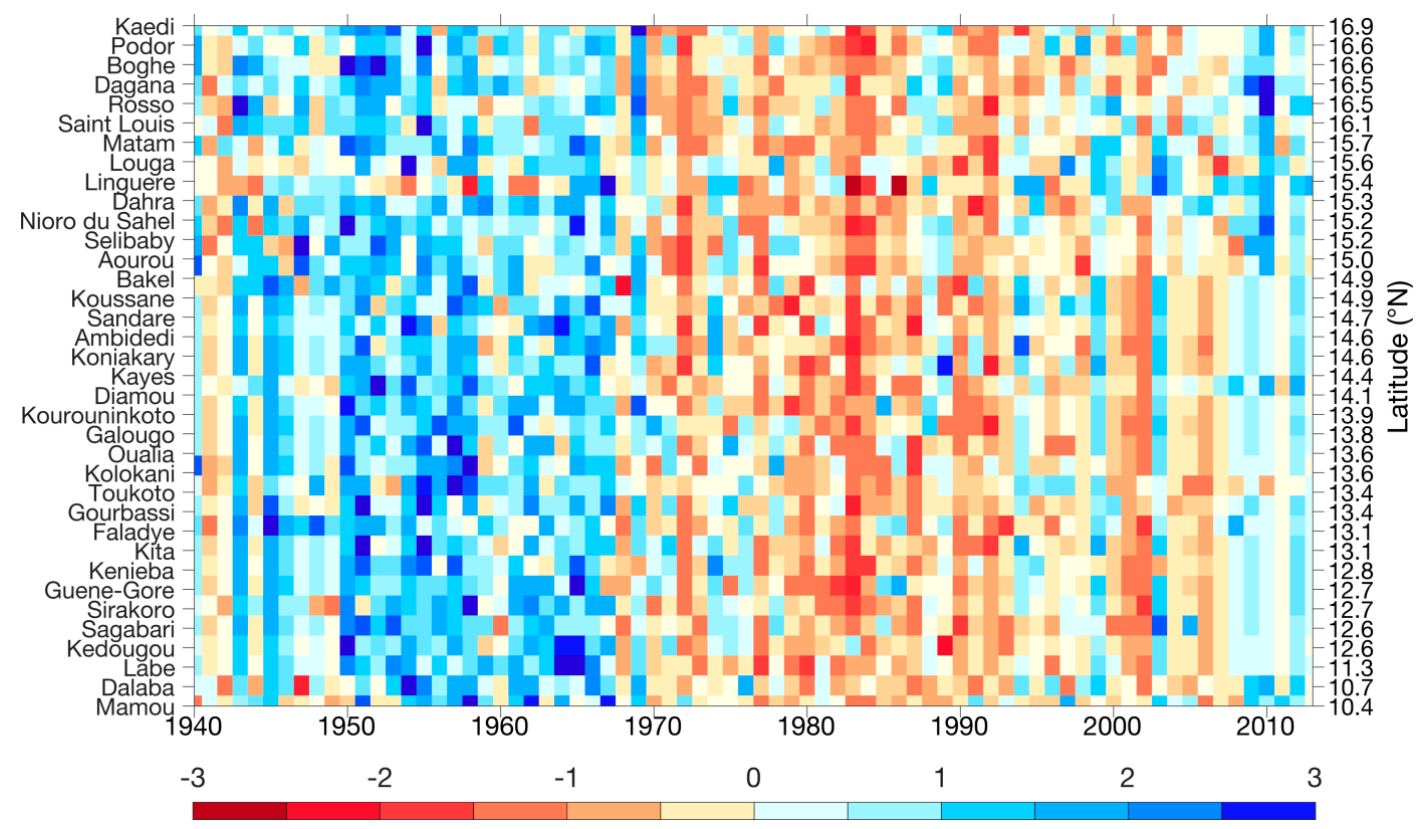

Figure 5. Variation of SPI over the period 1940-2013.

\subsection{Annual Rainfall Trend}

The trend in annual rainfall is investigated from 1940 to 2013 for both the whole annual rainfall series and the periods after the first shift to 2013. For the whole period (1940-2013), Figure 6a shows that the spatial pattern is dominated by a downward trend except Bakel which exhibits an upward trend but not significant at a 5\% significance level. The case of Bakel was mentioned by previous studies [28,37]. However, the period after the first shift to 2013 (Figure 6b) shows a significant positive linear trend (0.05) at the majority of the stations in the Senegal River basin. There are few stations mainly at the upper part of the river basin which exhibit a non-significant positive trend. These results indicate that the Sahelian part of the river basin exhibits a significant upward trend of annual rainfall, whereas the Soudanian one shows an upward trend but is not significant. 

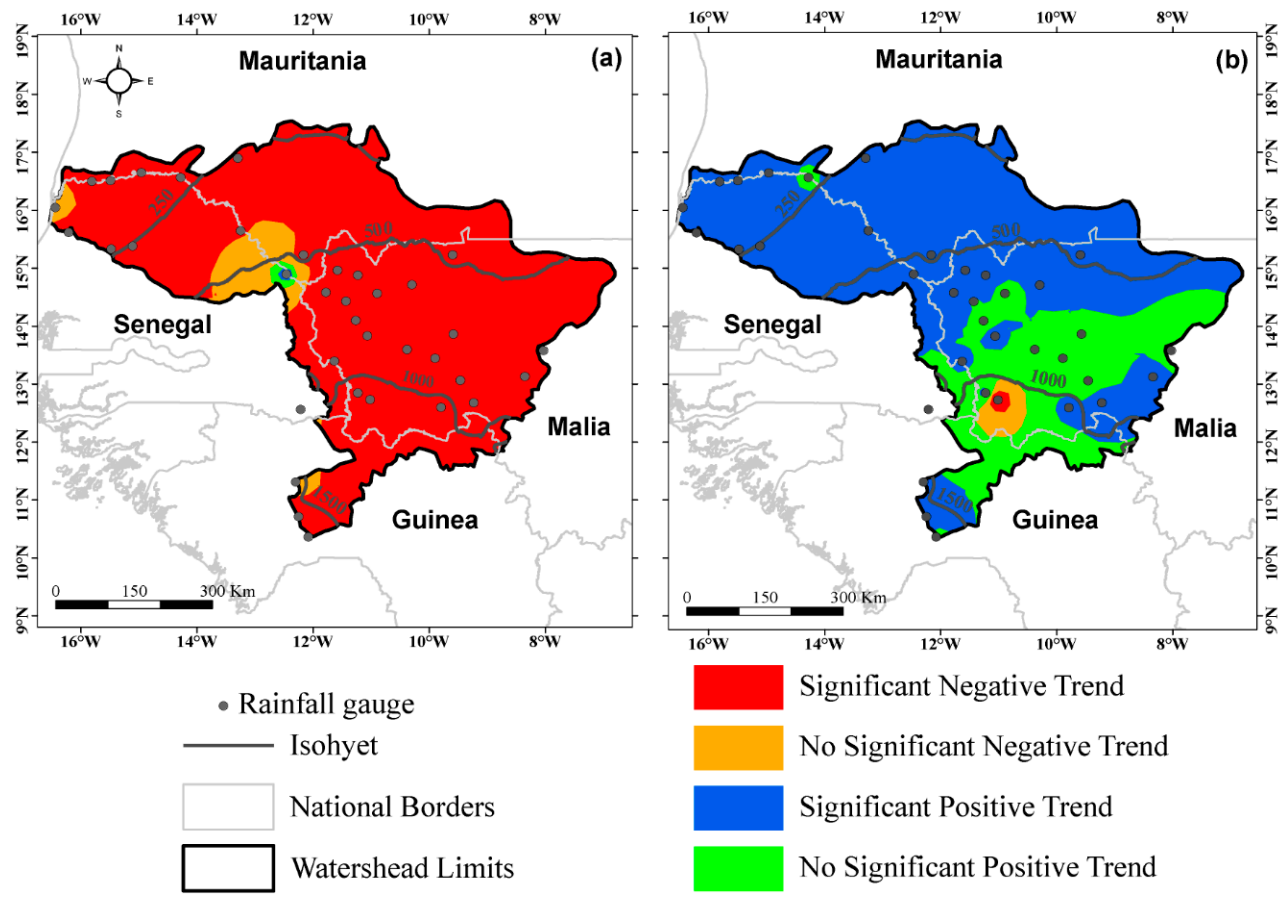

Figure 6. Spatial distribution of the statistics $\mathrm{Z}$ of the Mann-Kendall test for the annual rainfall (a) period 1940-2013; (b) period after shift 1 to 2013.

\subsection{Evolution of Hydrological Variables}

An analysis was performed in order to evaluate the variability of the hydrologic variables across the three sub-basins of the area: Gourbassi, Oualia and Dakka Saidou for the period from 1940 to 2013 (Table 2 and Figure 7). Both rainfall and hydrologic variables: AAFR, MADF, LFR seem to have similar trends. For all basins, the period before the first break was the wettest with average rainfall varying from $877 \mathrm{~mm}$ (Oualia) up to $1239 \mathrm{~mm}$ (Gourbassi). Table 2 presents the relative change computed before and after breaks for all variables and for each sub-basin. The table shows that the relative changes differ based on the variables and the sub-basin. Relative changes before (1940-1969) and after first break (1970-2013) are significantly negative (0.05) for all variables. The highest relative changes are observed for the AAFR reaching $-54 \%$ in Gourbassi sub-basin. When considering the periods before 1970-1994 and second shifts (1995-2013), the relative changes are mainly significantly positive (0.05) except for the LFR. These results are further supported by the tabulated SPI presented above.

Table 2. Mean, standard deviation and changes in hydroclimatic variables.

\begin{tabular}{|c|c|c|c|c|c|c|c|c|c|c|c|}
\hline \multirow{3}{*}{ Basin } & \multirow{3}{*}{ Parameters } & \multirow{2}{*}{\multicolumn{2}{|c|}{$\begin{array}{c}\text { Long Term Period } \\
1940-2013\end{array}$}} & \multirow{2}{*}{\multicolumn{2}{|c|}{\begin{tabular}{|c|} 
Period 1 \\
$1940-1969$
\end{tabular}}} & \multirow{2}{*}{\multicolumn{2}{|c|}{$\begin{array}{c}\text { Period } 2 \\
1970-1994\end{array}$}} & \multirow{2}{*}{\multicolumn{2}{|c|}{$\begin{array}{c}\text { Period } 3 \\
1995-2013\end{array}$}} & \multicolumn{2}{|c|}{ Change } \\
\hline & & & & & & & & & & \multirow{2}{*}{$\begin{array}{c}\text { Break } 1 \\
\Delta 1\end{array}$} & \multirow{2}{*}{$\begin{array}{c}\text { Break } 2 \\
\Delta 2\end{array}$} \\
\hline & & $\bar{X}$ & $\sigma$ & $\bar{X}$ & $\sigma$ & $\bar{X}$ & $\sigma$ & $\bar{X}$ & $\sigma$ & & \\
\hline \multirow{4}{*}{ Gourbassi } & Rainfall & 1125 & 171 & 1239 & 97 & 990 & 89 & 1111 & 86 & $-0.15 *$ & 0.12 \\
\hline & AAFR & 101 & 52 & 168 & 38 & 67 & 33 & 92 & 29 & -0.54 * & 0.37 * \\
\hline & MADF & 922 & 429 & 1359 & 356 & 682 & 358 & 899 & 318 & -0.43 * & 0.32 * \\
\hline & LFR & 26 & 11 & 31 & 8 & 20 & 9 & 31 & 13 & -0.18 * & 0.58 \\
\hline \multirow{4}{*}{ Oualia } & Rainfall & 822 & 117 & 887 & 147 & 715 & 127 & 855 & 120 & $-0.12 *$ & 0.20 * \\
\hline & AAFR & 117 & 67 & 202 & 39 & 69 & 40 & 99 & 42 & -0.58 * & $0.44 *$ \\
\hline & MADF & 1041 & 605 & 1578 & 408 & 666 & 429 & 1066 & 614 & $-0.46^{*}$ & 0.60 * \\
\hline & LFR & 39 & 18 & 62 & 12 & 31 & 10 & 29 & 11 & -0.51 * & -0.04 \\
\hline \multirow{4}{*}{$\begin{array}{l}\text { DakKa } \\
\text { Saidou }\end{array}$} & Rainfall & 1472 & 198 & 1629 & 164 & 1282 & 125 & 1461 & 123 & $-0.16^{*}$ & 0.14 * \\
\hline & AAFR & 228 & 64 & 309 & 53 & 180 & 34 & 223 & 26 & -0.35 * & $0.24 *$ \\
\hline & MADF & 1328 & 472 & 1796 & 540 & 1053 & 228 & 1311 & 376 & -0.35 * & 0.24 * \\
\hline & LFR & 40 & 11 & 48 & 18 & 38 & 6 & 36 & 5 & -0.23 * & $-0.05^{*}$ \\
\hline
\end{tabular}

LFR, low flow rate $\left(\mathrm{m}^{3} / \mathrm{s}\right) ;$ MADF, maximum daily flow $\left(\mathrm{m}^{3} / \mathrm{s}\right) ;$ AAFR, average annual flow rate $\left(\mathrm{m}^{3} / \mathrm{s}\right) ; \Delta 1$, relative change between period before and after shift $1(\%) ; \Delta 2$, relative change between period before and after shift $2(\%)$. * Significant changes at the $5 \%$ threshold. 

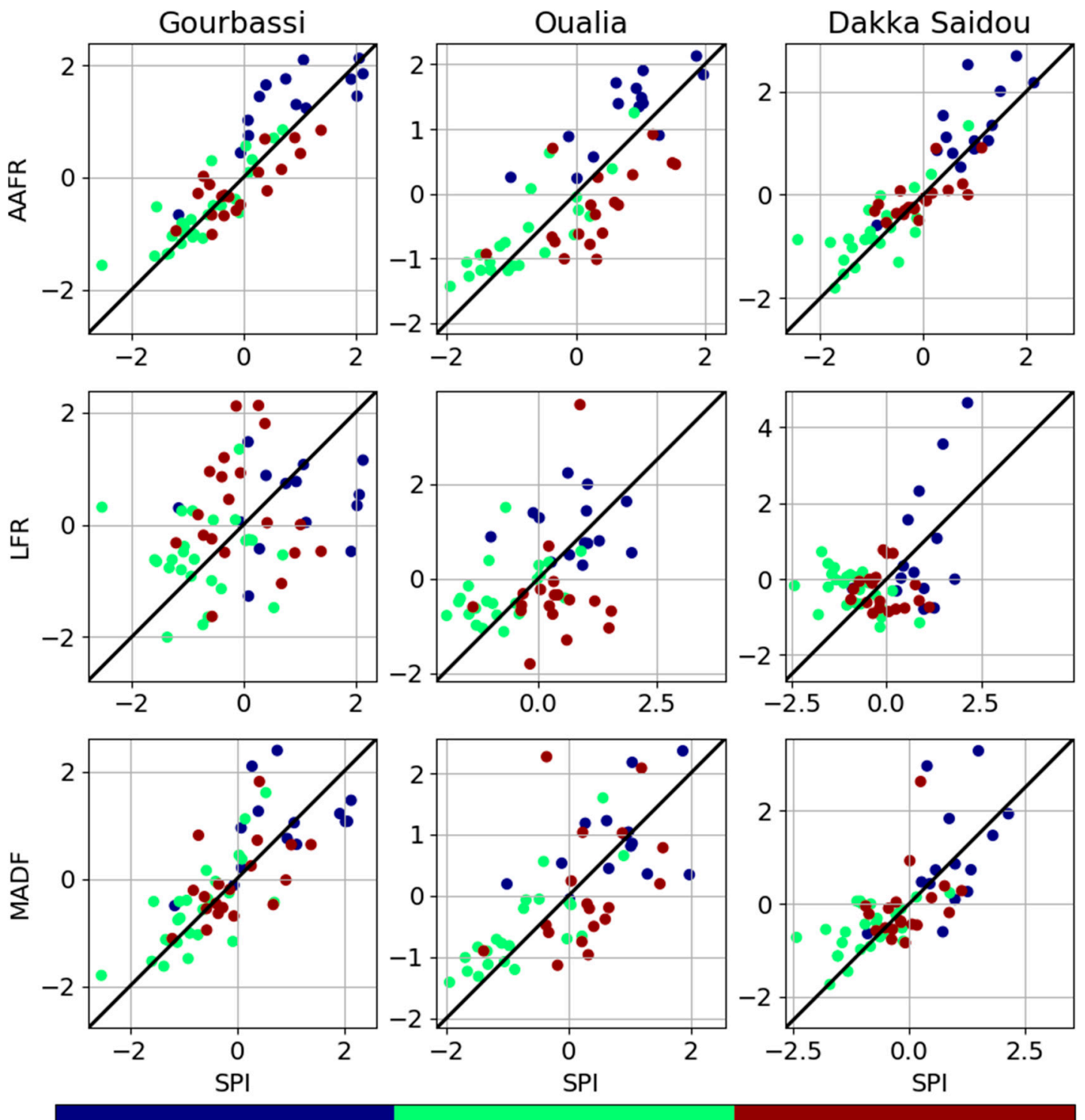

1940

1969

1994

2013

Figure 7. Relationship between SPIs and hydrological variables.

\section{Discussion}

The results of this paper show two main shifts on annual rainfall in 1969 and 1994 which corroborates the results of Nicholson et al. [19] who showed that a major change in the rainfall regime occurred in both the Sahel and Guinea Coast around 1968/1969. The annual rainfall exhibited a decreasing trend if we considered the whole series. This decreasing trend of the annual rainfall has the same consequence on the hydroclimatic variables: AAFR, MADF, LFR. This is in accordance with Olivry [42] who found a net relationship between annual rainfall and hydoclimatic variables in terms of trend. In addition, Diop et al. [43] by investigating the annual streamflow in the upper Senegal River basin found a significant decreasing trend from 1961 to 2014.

The first shift (1969) marks the starting point of the drought as indicated by the values of the SPI. Our results suggest an onset of the drought similar to that found by Nichloson et al. [19]. After the second shift (1994), there is an increase of annual rainfall compared to the previous period (1969-1994) which indicated a partial rainfall recovery not significant at a basin level.

Hence, the paper confirms the findings suggesting a return of wet period $[18,28,44,45]$. This leads to an improvement in water availability. The relative changes between period before and after second 
shift range from 0.24 (Dakka Saidou) to 0.60 (Oualia) for MADFs, from 0.24 (Dakka Saidou) to 0.44 (Oualia) for AAFRs and from 0.58 (Gourbassi) to -0.04 (Oualia and Dakka Saidou). With the exception of the low water flows of Oualia and Dakka Saidou, the various hydrological variables analysed show an uptrend. Flows were sustained for a few years at the beginning of the drought by emptying natural reservoirs; it now takes a few years to restore them. However, the relative change of 0.58 for the Gourbassi low water flow does not seem realistic and may be implied by associated uncertainty with the calculation of low water flows. Indeed, the calculation of low water flows requires the separation of flows. This separation of flows was carried out based on the decrease in the annual hydrograph, which corresponds to a regular decrease in flows or drying phase. After rapid flows transfer, the part of the curve with the steep slope corresponds to the recession and the part that shows a gentle slope to drying up [46] that begins in late November or early December in our study area. This method permits to calculate the annual drying coefficients and corresponding low water flows. However, flow separation is hardly possible for a large river [47] and this can affect the calculated low water flows and lead to discrepancies in the results between stations. In addition, the calibration curves of the different stations used in the study back to the 1950s (1950 for Gourbassi, 1952 for Dakka Saidou and 1954 for Oualia). The existence of probable unearthing can persist at the level of the various hydrometric stations with a greater influence on low water flows than on the other hydrological variables. The reasons for this failure to update the calibration curves are various. Indeed, in recent decades, countries which share the Senegal River basin (Guinea-Conakry, Mali, Senegal and Mauritania) have difficulties in providing hydrological monitoring of the river and its tributaries correctly because of a lack of human and financial resources [48]. Over the last few years, African hydrological services have difficulty to ensure water resource monitoring, resulting in significant gaps in streamflow series. The reasons for the discontinuity of data are part of budgetary austerity measures imposed by international financial institutions.

\section{Conclusions}

Analyzing trends of annual rainfall and assessing the impacts of these trends on the hydrological regime are crucial in a context of climate and global change and increasing water use. This paper investigates the recent trend of hydroclimatic variables in the Senegal River basin based on 36 rain gauge stations and 3 hydrometric stations not influenced by hydraulic structures. Results show two main shifts on annual rainfall in 1969 and 1994. The first shift (1969) marks the starting point of the drought as indicated by the values of the SPI. After the second shift (1994), there is an increase of annual rainfall compared to the previous period (1969-1994) which indicated a partial rainfall recovery not significant at a basin level.

Overall, these findings demonstrate that there is a recovery of annual rainfall in the Senegal River basin which is leading to the improvement of surface water availability. However, we cannot affirm with precision if this recovery is significant and persistent unless we have a longer data series. Therefore, it is crucial and necessary to have access to recent hydroclimatic data in order to further investigate the so-called recovery period.

Author Contributions: Conceptualization, A.B. and L.D.; methodology, A.B. and L.D.; software, A.B., L.D., G.P., P.M.N.; validation, A.D. (Alain Dezetter), T.V., H.D., and A.D. (Abdoulaye Deme); formal analysis, A.B., L.D., G.P., A.D. (Alain Dezetter), T.V.; data curation, A.B., H.D., I.D.; writing-original draft preparation, A.B. and L.D.; writing-review and editing, A.B., L.D., G.P., A.D. (Alain Dezetter), T.V., I.D., P.M.N.; All authors have read and agreed to the published version of the manuscript.

Funding: This research received no external funding.

Acknowledgments: The authors express their gratitude to the hydrological and meteorological services of the member countries of the Senegal River Basin Development Organization. We would like to thank the IRD and IGE for there technical and financial supports. The authors also thank the three reviewers and the editors.

Conflicts of Interest: The authors declare no conflict of interest. 


\section{References}

1. Sarr, M.A.; Zorome, M.; Seidou, O.; Bryant, C.R.; Gachon, P. Recent trends in selected extreme precipitation indices in Senegal-A changepoint approach. J. Hydrol. 2013, 505, 326-334. [CrossRef]

2. Sircoulon, J. Les données hydropluviométriques de la sécheresse récente en Afrique intertropicale. Comparaison avec les sécheresses "1913" et "1940". Cah. Orstom Ser. Hydrol. 1976, 13, 75-174.

3. Servat, E.; Paturel, J.E.; Lubes-Niel, H.; Kouamé, B.; Masson, J.M.; Travaglo, M.; Marieu, B. De différents aspects de la variabilité de la pluviométrie en Afrique de l'Ouest et Centrale. J. Water Sci. 1999, 12, 363-387. [CrossRef]

4. Liénou, G. Impacts de la Variabilité Climatique sur les Ressources en eau et les Transports de Matières en Suspension de Quelques Bassins Versants Représentatifs au Cameroun. Ph.D. Thesis, Yaoundé I University, Yaoundé, Cameroon, 2007.

5. Hulme, M.; Doherty, R.; Ngara, T.; New, M.; Lister, D. African climate change: 1900-2100. Clim. Res. 2001, 17, 145-168. [CrossRef]

6. Hubert, P.; Bader, J.C.; Bendjoudi, H. Un siècle de débits annuels du fleuve Sénégal. J. Sci. Hydrol. 2007, 52, 68-73. [CrossRef]

7. Abrate, T.; Hubert, P.; Sighomnou, D. A study on hydrological series of the Niger River. Hydrol. Sci. J. 2013, 58, 1-9. [CrossRef]

8. Olivry, J.C. Les conséquences durables de la sécheresse actuelle sur l'écoulement du fleuve Sénégal et l'hypersalinisation de la Basse-Casamance. In The influence of Climate Change and Variability on the Hydrologic Regime and Water Resources, Proceedings of the Vancouver Symposium, Vancouver, BC, Canada, 9-22 August 1987 Canada; IAHS Publication: Wallingford, UK, 1987.

9. Lamb, P.J. Persistence of sub-Saharan drought. Nature 1982, 299, 46-47. [CrossRef]

10. Carbonnel, J.P.; Hubert, P. Sur la sécheresse au Sahel d'Afrique de l'Ouest. Une rupture climatique dans les séries pluviométriques du Burkina-Faso (ex Haute-Volta). C. R. Acad. Sci. 1985, 301, 941-944.

11. Nicholson, S.E. The spatial coherence of African rainfall anomalies: Interhemispheric teleconnections. J. Clim. Appl. Meteorol. 1986, 25, 1365-1381. [CrossRef]

12. L'hôte, Y.; Mahé, G.; Somé, B.; Triboulet, J.P. Analysis of a Sahelian annual rainfall index from 1896 to 2000; the drought continues. Hydrol. Sci. J. 2002, 47, 563-572. [CrossRef]

13. Dacosta, H.; Konaté, Y.K.; Malou, R. La variabilité spatio-temporelle des précipitations au Sénégal depuis un siècle. In Regional Hydrology: Bringing the Gap between Reseach and Pratice (FRIEND Conference, Le Cap, Afrique $d u$ Sud); IAHS Publication: Wallingford, UK, 2002; pp. 499-506.

14. Niel, H.; Leduc, C.; Dieulin, C. Caractérisation de la variabilité spatiale et temporelle des précipitations annuelles sur le bassin du Lac Tchad au cours du 20ème siècle. Hydrol. Sci. J. 2005, 50, 223-243. [CrossRef]

15. Ali, A.; Lebel, T. The Sahelian standardized rainfall index revisited. Int. J. Climatol. 2009, 29, 1705-1714. [CrossRef]

16. Lebel, T.; Ali, A. Recent trends in the Central and Western Sahel rainfall regime (1990-2007). J. Hydrol. 2009, 375, 52-64. [CrossRef]

17. Mahé, G.; Paturel, J.E. 1896-2006 Sahelian annual rainfall variability and runoff increase of Sahelian Rivers. C. R. Geosci. 2009, 341, 538-546. [CrossRef]

18. Sanogo, S.; Fink, A.H.; Omotosho, J.A.; Ba, A.; Redl, R.; Ermert, V. Spatio-temporal characteristics of the recent rainfall recovery in West Africa. Int. J. Clim. 2015, 35, 4589-4605. [CrossRef]

19. Nicholson, S.E.; Fink, A.H.; Funk, A. Assessing recovery and change in West Africa's rainfall regime from a 161-year record. Int. J. Clim. 2018, 38, 3770-3786. [CrossRef]

20. Sene, S.; Ozer, P. Évolution pluviométrique et relation inondations-événements pluvieux au Sénégal. Bull. Soc. Geogr. Liège 2002, 42, 27-33.

21. Ozer, P.; Erpicum, M.; Demarée, G.; Vandiepenbeck, M. The Sahelian drought may have ended during the 1990s. Hydrol. Sci. J. 2003, 48, 489-492. [CrossRef]

22. Diello, P. Interrelations Climat-Homme-Environnement dans le Sahel Burkinabé: Impacts sur les états de surface et la modélisation hydrologique. Ph.D. Thesis, University of Montpellier, Montpellier, France, 2007.

23. Ardoin, S.; Lubés-Niel, H.; Servat, E.; Dezetter, A.; Paturel, J.E.; Mahé, G.; Boyer, J.F. Analyse de la persistance de la sécheresse en Afrique de l'Ouest: Caractérisation de la situation de la décennie 90. In Hydrology of the Mediterranean and Semiarid Regions (Colloque IAHS, Montpellier); Servat, É., Najem, W., Leduc, C., Ahmed, S., Eds.; IAHS Publication: Wallingford, UK, 2003; pp. 223-228. 
24. Vischel, T.; Lebel, T.; Panthou, G.; Quantin, G.; Rossi, A.; Martineti, M. Le retour d'une période humide au Sahel ? Observations et perspectives. In Les Sociétés Rurales Face aux Changements Climatiques et Environnementaux en Afrique de l'Ouest; Sultan, B., Lalou, R., Sanni, M.A., Oumarou, A., Soumaré, M.A., Eds.; Collection Synthèses; IRD Editions: Marseille, France, 2015; pp. 43-60.

25. Panthou, G.; Vischel, T.; Lebel, T.; Quantin, G. Rainfall intensification in tropical semi-arid regions: The Sahelian case. Environ. Res. Lett. 2018, 13, 064013. [CrossRef]

26. Nkrumah, F.; Vischel, T.; Panthou, G.; Klutse, N.A.B.; Adukpo, D.C.; Diedhiou, A. Recent Trends in the Daily Rainfall Regime in Southern West Africa. Atmosphere 2019, 10, 741. [CrossRef]

27. Descroix, L.; Guichard, F.; Grippa, M.; Lambert, L.A.; Panthou, G.; Mahe, G.; Gal, L.; Dardel, C.; Quantin, G.; Kergoat, L.; et al. Evolution of surface hydrology in the sahelo-sudanian strip: An updated review. Water 2018, 10, 748. [CrossRef]

28. Diop, L.; Bodian, A.; Diallo, D. Spatiotemporal Trend Analysis of the Mean Annual Rainfall in Senegal. Eur. Sci. J. 2016, 12, 231-245. [CrossRef]

29. Kuentz, A. Un Siècle de Variabilité Hydro-Climatique sur le Bassin de la Durance: Recherches Historiques et Reconstitutions. Ph.D. Thesis, Agro Paris Tech, Paris, France, 2013.

30. Dione, O. Evolution Climatique Récente et Dynamique Fluviale Dans les Hauts Bassins des Fleuves Sénégal et Gambie. Ph.D. Thesis, Université Jean Moulin Lyon 3, Lyon, France, 1996. Available online: http://horizon.documentation.ird.fr/exl-doc/pleins_textes/pleins_textes_7/TDM_7/010012551.pdf (accessed on 9 December 2019).

31. Bodian, A. Approche par Modélisation Pluie-Débit de la Connaissance Régionale de la Ressource en eau: Application au Haut Bassin du Fleuve Sénégal. Ph.D. Thesis, Université Cheikh Anta Diop de Dakar, Dakar, Sénégal, 2011. Available online: http://hydrologie.org/THE/BODIAN.pdf (accessed on 9 December 2019).

32. Bodian, A.; Dezetter, A.; Dacosta, H. Apport de la modélisation hydrologique pour la connaissance de la ressource en eau: Application au haut bassin du fleuve Sénégal. Climatologie 2012, 9, 109-125.

33. Brunet-Moret, Y. Test d'homogénéité. Cah. Orstom Ser. Hydrol. 1977, 14, 119-129.

34. Hiez, G. Bases théoriques du "Vecteur Régional". Les premières applications et leur mise en œuvre informatique. In Deuxièmes Journées Hydrologiques de l'ORSTOM (Montpellier); Editions de l'ORSTOM: Ballan-Miré, France, 1986; pp. 1-35.

35. Hiez, G.; Cochonneau, G.; Sechet, P.; Fernandes, U.M. Application de la méthode du vecteur régional à l'analyse de la pluviométrie annuelle du bassin versant amazonien. Veill. Clim. Satellitaire 1992, 43, 39-52.

36. Henseler, J.; Ringle, C.; Sinkovics, R. The use of partial least squares path modeling in international marketing. Adv. Int. Mark. 2009, 20, 277-320.

37. Bodian, A. Caractérisation de la variabilité temporelle récente des précipitations annuelles au Sénégal (Afrique de l'Ouest). Physio Géo 2014, 8, 297-312. [CrossRef]

38. Mann, H.B. Nonparametric tests against trend. Econ. J. Econ. Soc. 1945, 13, 245-259. [CrossRef]

39. Kendall, M.G. Further contributions to the theory of paired comparisons. Biometrics 1955, 11, 43-62. [CrossRef]

40. Pettitt, A.N. A non-parametric approach to the change-point problem. J. R. Stat. Soc. Ser. C Appl. Stat. 1979, 28, 126-135. [CrossRef]

41. Ali, A.; Lebel, T.; Amani, A. Signification et usage de l'indice pluviométrique au Sahel. Sécheresse 2008, 19, 227-235.

42. Olivry, J.C. De l'évolution de la puissance des crues des grands cours d'eau intertropicaux d'Afrique depuis deux décennies. In Potamologie d'Hier et d'Aujourd'hui, Aménagements et Cours d'eau. Actes des Journées Hydrologiques-Centenaire Maurice Pardé Grenoble; Vivian, H., Ed.; Institut de Géographie Alpine: Grenoble, France, 1994; pp. 101-108.

43. Diop, L.; Yaseen, Z.M.; Bodian, A.; Djaman, K.; Brown, L. Trend analysis of streamflow with different time scales: A case study of the upper Senegal River. ISH J. Hydraul. Eng. 2017. [CrossRef]

44. Giannini, A.; Salack, S.; Lodoun, T.; Ali, A.; Gaye, A.T.; Ndiaye, O. A unifying view of climate change in the Sahel linking intra-seasonal, interannual and longer time scales. Environ. Res. Lett. 2013, 8, 024010. [CrossRef]

45. Panthou, G.; Vischel, T.; Lebel, T. Recent trends in the regime of extreme rainfall in the Central Sahel. Int. J. Clim. 2014, 34, 3998-4006. [CrossRef] 
46. Malanda, E.N. Etude Statistique et Modélisation Pluie-Débit à la l'Aide des Modèles Conceptuels Globaux GR4J et GR2M: Applications sur le Bassin Versant du Fleuve Gambie à la Station de Kédougou. Ph.D. Thesis, Université Cheikh Anta Diop, Dakar, Sénégal, 2009.

47. Olivry, J.C. Etude régionale sur les basses eaux; les effets durables du déficit des précipitations sur les étiages et les tarissements en Afrique de l'ouest et du centre. In XII émes Journée Hydrologiques de l'Orstom (Montpellier); Editions de l'ORSTOM: Ballan-Miré, France, 1996; p. 14.

48. Bodian, A.; Dezetter, A.; Dacosta, H. Rainfall-Runoff Modelling of Water Resources in the Upper Senegal River Basin. Int. J. Water Resour. Dev. 2015, 32, 89-101. [CrossRef]

(C) 2020 by the authors. Licensee MDPI, Basel, Switzerland. This article is an open access article distributed under the terms and conditions of the Creative Commons Attribution (CC BY) license (http://creativecommons.org/licenses/by/4.0/). 